\title{
Pangs of nascent nationalism from the nationless state? Euro coins and undocumented migrants in Malta since $2004 *$
}

\author{
GODFREY BALDACCHINO \\ University of Prince Edward Island, Canada and Visiting Professor, University \\ of Malta, Malta
}

\begin{abstract}
This paper examines recent manifestations of the emergence of national identity amongst the citizens of Malta, now the smallest member state of the European Union. In this search, discrete events and 'things' are examined as symbolic paraphernalia, empirical phenomena that provide insights to overarching narratives about identity, nationalism and integration. The discussion and eventual decision on the choice of euro coin faces in Malta is proposed as one that illustrates a process of 'nascent nationalism'. Meanwhile, the arrival of boatloads of undocumented migrants on Malta's shores has also encouraged the evolution of a secular, national character in Malta. Such episodes, and others, ultimately reflect a need for symbols of national unity that remain largely absent in this 'nationless state' which continues to be gripped by a bipolar partisanship that spares almost no one.
\end{abstract}

KEYWORDS: euro coins; European Union; Malta; nationalism; nationless state; undocumented migrants

\section{Scene-setting: there are two sides to the coin}

The choice of stylised bridges to grace the reverse side of the euro notes, now the currency of 400 million Europeans, should not surprise us. The European Union (EU) is a grand project which speaks ambitiously to both integration

\footnotetext{
* An earlier draft of this paper was prepared for a workshop titled: 'EU-Civil Society Relations: The Impact of the EU on National Movements and National Identity', organised by the Department of Politics at the University of Strathclyde and held at Ross Priory, Loch Lomond, Scotland, on 23-25 April 2007. My thanks to workshop organiser Laura Cram and fellow attendees Richard Wyn Jones, Neil MacCormick, James Mitchell, Caesar Mavratsas and Jirí Pribán. Further thanks to Mark Cauchi, David Fabri, Gorg Mallia, Peter Mayo, Carmen Sammut and Sharon Spiteri for comments on an earlier draft, to Charles Saliba for research support, and to the various copyright holders for their permission to reproduce visual material. The final draft owes much to the comments of the editor of Nations and Nationalism and two anonymous reviewers. Responsibility for errors and omissions is only mine.
} 
and insulation. While there are strong movements in favour of a deepening and widening of European-wide initiatives, as is the very notion of a single European currency, at the same time the EU remains essentially a platform for the advancement or protection of stubbornly state-based interests. The bridges epitomise the concept of the single market, of 'building Europe' (Sidaway 2001: 743); yet they remind us of the separate units ('nation-states'?) that make the bridge and its bridging functions necessary. Meanwhile, though the euro notes are the same everywhere, the euro coins portray, on one side, national monuments and symbols from each member state; with a common rendition of the map of Europe on the other side (van Houtum and Strüver 2002: 145). The coins therefore better capture the integrationist and localist thrusts of the European projects, each of these represented on either of the coins' two sides.

The choice of what to reproduce on the obverse of the euro coins has proved to be an interesting matter for debate. ${ }^{1}$ The exercise has obliged euro zone countries to determine appropriate symbols of national stature, which both identify with the presumed identity of the state, as well as differentiate that state from any other. 'The images on bills and coins are usually chosen carefully in order to connect with historical and sometimes nationalist symbols of the various nation-states' (Risse 2003: 488). In any case, the eventual choice of the national icons minted on the coins can serve as a reflexive exercise on the contemporary perceptions of nationhood and national identity, as well as its 'branding' in a regional context.

\section{The task at hand}

In semi-autobiographic style, this paper examines manifestations of the emergence of national identity amongst the Maltese, now the citizens of the smallest member state of the EU in both land area and population. In this search, the choice of euro coin images by the Maltese, and the boatloads of undocumented migrants arriving on Malta's shores from Africa, are just two of a series of episodes that are insightful illustrations of a process that can be seen as indicative of a 'nascent nationalism'. This is so because Malta may have been a politically distinct state for centuries, but it is one whose people find enormous difficulties in projecting or imagining themselves as a nation, except in a vague and distant cultural sense. Maltese sociologist Abela (2006: 19) refers to this condition ambiguously as a 'two-nation party-political divide within one social nation'.

I suggest that the discussion and eventual decision on the choice of the euro coin faces in Malta is one that ultimately reflects a search for still absent symbols of national unity. The coming to terms with the alterity of darkskinned, non-Christian undocumented migrants from Africa, and the position that Brussels, seat of the EU bureaucracy, is seen to be taking on this 'invasion', are similarly symptomatic of this quest for identity. This search 
remains stifled by a bi-communal partisanship that sees each of the two main political parties take on the characteristics of an ethnie, ${ }^{2}$ a moral community, extending the locus of empathy, trust and identification with others as if in an extended family (Baldacchino 2002a: 198; Srebrnik 2000: 57). An insightful, non-Maltese researcher commented:

Partisanship in this polarized polity is so pervasive, ingrained and linked to class ideology and locality that preference patterns are known by street. Loyalties are strong, stable and rooted in social and family background(Hirczy 1995: 258).

The paper will examine discrete events and 'things' as symbolic paraphernalia that are illustrative, as well as symptomatic, of the current fledgling character of Maltese nationalism. A series of empirical phenomena are thus presented with a view to providing insights into overarching narratives about identity, nationalism and integration. The style is largely inductive, seeking to theorise 'from the bottom up' on the basis of reflections on specific recent historical events.

In this paper, the product of national identity is taken to imply a 'we', a people with common historical characteristics (which include shared memories of the past and visions of the future) that are largely symbolic but sustained and refreshed by daily practices and routines (as suggested by Billig 1995; see also Jacobs and Maier 1997: 17). While elites may and do construct national identities, and different elites may craft divergent identities meant for the same citizens, theorists such as Anthony D. Smith contend that such disagreements would still ride over a solid core of unifying elements, providing '. . a sense of continuity, shared memory and collective destiny' (Smith 1991: 29; 2004: 197).

This paper argues that, while the Maltese share a common language and have no readily perceptible racial, ethnic or rural/urban cleavages, the partisan political mobilisation of both state and civil society effectively erodes 'unifying elements' or transforms them (at least perceptively) to partisan appropriation and symbolic use. Moreover, there is no strong sense of cultural and linguistic discontinuity with outsider-nations (following Hannerz 1996: 21). Thus, Malta is presented as a polarised, deeply divided, 'nationless state'.

\section{Upside-down decolonisation}

One of the difficulties facing the Maltese in sharing a self-image of themselves is that, while they have borne many centuries of colonialism, they have not been champions of anti-colonialism. Rather, the opposite has been the case. Only in the case of the brief French Occupation (1798-1800) did the Maltese rise up as a people against their oppressors, and then only because the French had foolishly decided to start ransacking the Catholic churches which the Maltese still hold dear. Over the long British period of colonial administration (1800-1964), the Maltese adapted to a cycle of boom and bust that depended significantly on military expenditure: ironically, peace time brought poverty 
and unemployment; whereas the threat of, or actual, war brought work and munificence (Baldacchino 1988; Busuttil 1965; Zammit 1984). Malta became a specialised fortress economy, playing such a key role in the Mediterranean theatre during the Second World War that the country was given the George Cross, now displayed on its flag. Yet, after the 1956 Suez debacle, when Britain decided to trim its strategic outposts in line with its much-reduced global stature, Malta suddenly became dispensable, its strategic value redundant. The Maltese Government resigned in 1958, police stations were burnt, the constitution was revoked . . . essentially because the Maltese did not want the British (with their war machine expenditures) to pull out. Eventually, independence was secured in 1964 and an agreement was signed in 1972 to extend the rundown of the British bases (plus the payment of rent) in Malta to 1979. The Maltese, unlike many other colonies, never fought any wars of independence to get rid of the colonial yoke; instead, they resorted to some quite ingenious international political lobbying to oblige the colonial power to stay longer .... and in the meantime inject more precious cash into the local economy (see e.g. Micallef 1979).

This is not a unique example of 'upside-down decolonisation', where the colonial ruler is the one keen to ditch the colony and force it into independence, while the colonised are generally keen to extend the colonial relationship (e.g. Hoefte and Oostindie 1989; Payne 1991). In fact, many island jurisdictions around the world have perfected this attitude so well that they have consistently refused to accept full independence. Referenda in the Dutch Antilles (1993, 1994, 2005, 2006), Puerto Rico (1993), US Virgin Islands (1993), and Bermuda (1993) have all rejected independence by huge margins (Baldacchino 2004).

Political affiliation grants substantial economic advantages to small, nonsovereign, island units. These benefits include: free trade with, and export preference from, the parent country; social welfare assistance; ready access to external capital through special tax concessions; availability of external labour markets through migration; aid-financed infrastructure and communications; higher quality health and educational systems; natural disaster relief; and provision of external defence costs (McElroy and Mahoney 1999). What these arrangements tend to do, however, is to render the small island economy over-dependent on metropolitan fiscal transfers. Local politics becomes gripped by what kind of integration to seek with the metropolitan power. Integration is not an issue: only its details are subject to debate and negotiation. ${ }^{3}$

Malta may have secured political independence, contrary to sub-national island jurisdictions. But the evolution of its national identity has not kept pace with its emergence as a sovereign state. Interestingly, Malta's current political landscape was forged in the late 1880s when colonial Britain proposed to introduce English as the language of instruction in schools. The conservative elite in the country, led by lawyers, clerics and the learned intelligentsia, then spoke, studied and wrote in Italian: they understood that they could maintain 
social control if Italian remained the principal language of instruction and thus eventually of the church, state and legislature (Frendo 1979: 208). Meanwhile, the upcoming middle class realised that the English language presented a window of opportunity to break or somehow circumvent the monopoly power of the Italo-philes. Thus coalesced what would emerge as Malta's two main political parties: the Partito Anti-Riformista, blocking reform (with its name appropriately in Italian); and the Reform Party, in favour of reform (with its name in English) (Hull 1993). The distinct Maltese language - the only Semitic language to be written in a Latin script - did not even feature in this debate: an alphabet for Maltese was only proposed in the late 1700s and standardised in 1924. The National Council for the Maltese Language was only established by law in $2004{ }^{4}$

\section{Integration options}

The epitome of these integrationist agendas was reached in the twentieth century when, faced with the challenges of development, the leaders of the two political camps explored the possibilities of integration with their respective motherlands: Italy and Britain. ${ }^{5}$

The Italian project was doomed to failure when planes started dropping bombs on the Maltese the day after Italy entered the war as Germany's ally in June 1940 (Mitchell 2003: 382). The leaders of the Nationalist Party (NP) (as the Partito Anti-Riformista was subsequently rechristened) were exiled to Uganda for the duration of the war because they were deemed too dangerous to stay on the island, given their fascist, pro-Italian sympathies.

The British project was later in coming but much more elaborate. A referendum was actually organised by the Malta Labour Party (MLP) in government in 1956 (as the Reform Party was then called) to explore the readiness of the Maltese to seek full integration with Britain. Although a slim majority did vote in favour, the low turnout (which was instigated by the local Roman Catholic Church, unsure of its status within a Protestant Britain: more on this below) was used by the British authorities as the excuse to disregard the result. It was only after the realisation that Britain was not seriously entertaining the integration option that Malta's two political parties switched their sights to political independence. Thus, the pursuit of full sovereignty was only a strategy of 'second best'.

It appears from their history that the Maltese have approached the whole business of independence and integration in a most pragmatic manner. The very open nature of the small local economy makes an export orientation essential; a large Maltese diaspora now resides in Australia, Canada, the USA and Britain and is responsible for much tourist traffic to/from the islands; even when the avowedly socialist Malta Labour Party was in power, the country's economic policy never faltered in seeking to attract foreign direct investment (Vella 1994). English is today an official language, along with 
Maltese. These circumstances have made for a very fluid jurisdiction, with on the one hand an international orientation that runs on written English, and makes the islands very attractive to tourists and expatriate retirees; while on the other hand having a domestic space that is driven by the Maltese language and word-of-mouth communication (e.g. Chircop 1994).

The Maltese language is the centre-piece of a rich and ancient culture that has found its major expression via the patronage of the local Catholic Church, especially since the early nineteenth century. The influence of the Catholic Church remains very strong in contemporary Malta: almost one-third of all students in primary and secondary education attend church schools; over half the population attends mass on Sunday; Malta is the only European country which does not legally sanction either divorce or abortion; and the conversion of the Maltese to Christianity by St Paul has been central to the national narrative (Mitchell 2002). The parish has also been the main expression of local governance in Malta; even with the introduction of local councils in the 1990s, the latter have quickly been taken over by the established political parties; to the extent that the parish remains the only safe space for nonpartisan local activity and organisation. With an estimated ninety-eight per cent of the local population professing to be Roman Catholic (e.g. Grixti 2006: 109), it is easy to see how, when everything else fails, the Roman Catholic Church takes on symbolic powers of national representation. ${ }^{6}$

\section{Partisan politics rule OK}

This rich cultural heritage has, however, not lent itself to the construction of nationhood as such. With the Catholic Church aligning itself against the referendum campaign of the Malta Labour Party in the mid-1950s, and with the understanding that the MLP leadership was harbouring communist sympathies, the Church excommunicated the MLP party leaders and its diehard sympathisers, refusing them holy sacraments or burial in sacred ground; and denouncing a vote for Labour as a 'mortal sin': a shocking turn of events in the twentieth century which destroyed the broad legitimacy that the religious institution until then had enjoyed amongst the populace-at-large.

The current configuration of the partisan divide has thus solidified: only the NP and MLP have been represented in Parliament since 1971; only a few thousand votes continue to separate them; and, given these circumstances, it should be no surprise that party discipline in the House is extreme. Strong, ascribed and inter-generational party loyalties fuel, and are in turn fuelled by, two parallel, political party juggernauts - which include party owned or driven neighbourhood committees, newspapers, radio and television stations - that attempt to lock, reinforce and secure voter loyalties from cradle to grave. A diffuse system of grass-roots organisation ensures that practically all voters are known for their political sympathies. Patronage, favouritism and clientelism are widely but discretely practised; and few would dare being seen 
as not voting, come election day: which explains why Malta has the highest electoral turnout in the world for democratic elections: no less than ninetyseven per cent (Hirczy 1995; Franklin 2004: 94-5).

The country is a stably pillarised society (following Lijphart 1968), split down the middle in terms of partisan support: a distinguishing feature in other societies. ${ }^{7}$ Unfolding as it does on a very small island jurisdiction where anonymity is hardly possible, the pressure to affiliate with one of two camps is intense; the only way to avoid this is 'ex-isle' (Edmond and Smith 2003); while, for those who stay, those who are not with us are obviously against us. Civil society is underdeveloped and, as far as it does exist, it is dangerously over-politicised. Since 1991, Malta has been the only European democracy to allow political parties to privately own radio and television stations (Sammut 2007). The divide extends dangerously to the interpretation of recent Maltese history. Thus, for example, the MLP does not consider Independence Day (21 September) to be the key defining event of Malta's political development, citing instead Freedom Day (31 March), the day commemorating when the last British troops left the island in 1979, as the really key episode. In its bid to establish a widely acceptable, single National Day in 1988, the Government ended up recognising the dilemma and opted for no less than five national days, the only country in the world to do so: a reflection of the absence of consensus on what is salient in recent Maltese history. ${ }^{8}$ Serracino-Inglott (1988: 370) has argued that, if one were to understand 'nation' as a discrete socio-cultural unit with collective aims, it is tempting to argue that Malta (especially in the 1970s and 1980s) consisted not of one nation, but of two, organised along political party lines. I would argue that this assessment remains valid.

Within this division, which came close to civil war in 1982-4, neither the Church nor any other local institution has been able to play a satisfactory bridging role. As a result, a nascent nationalism may be finding a frenzied but short-lived expression when an international event which is not associated with the local state (and therefore safely removed from domestic politics) kindles a therapeutic (but transient) burst of national pride and its identifiable heroes. Clear examples include the events following the securing of a runnerup position for local singer Ira Losco in the 47th Eurovision Song Contest in May 2002 (see Figures 1 and 2); ${ }^{9}$ and Malta beating Hungary 2-1 in a Euro 2008 Soccer Qualifying home match in October 2006. But then, on the other hand, even these manifestations could be just outbursts of patriotism. ${ }^{10}$

The above ideas were articulated in a paper published in an international journal (Baldacchino 2002a), then serialised over two parts in the Sunday Times of Malta, a local, high-circulation, weekly, English-language newspaper. The response was, expectedly, largely vicious. I have been accused of being unpatriotic, and of misreading Malta's history and character; but also commended for having dared utter the unutterable. I also participated in a live TV discussion in January 2003 with an eminent history professor who is a champion of Malta's alleged nationhood. ${ }^{11}$ During that programme, I asked 


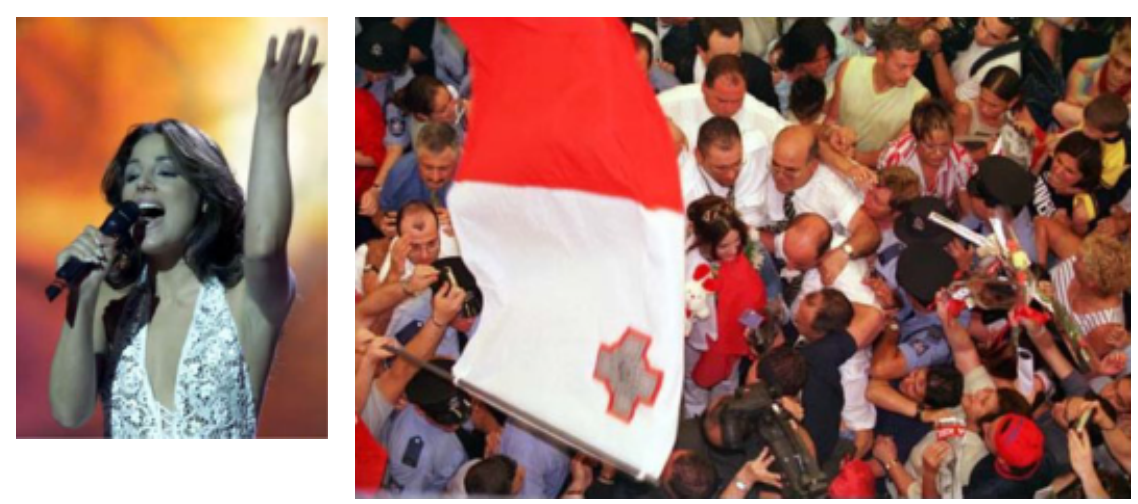

Figures 1 and 2. Displays of spontaneous nationalism: Maltese singer Ira Losco (left) being mobbed at Malta International Airport (right) after returning from the Eurovision Song Contest in Estonia. Photo on left: (C) 2002 MaltaMedia Productions. Photo on right by Darren Zammit Lupi, published in The Times, Malta, 28 May 2002. (C) Allied Newspapers Limited.

viewers whether they could identify any contemporary Maltese 'of stature' who would not be easily associated with one of the two main political parties. The question was meant to be rhetorical. The answer is: no. As I reported in my 2002 paper, a German entrepreneur living in Malta has insightfully observed that the Maltese are very proud of their (past) history, but not of their present. As long as events are telescoped back into the past, a past when political disagreement is not seen as having been institutionalised in terms of political parties and therefore candidly assumed to have been overtaken by 'national interests', then most Maltese can agree as to the interpretation and relevance of events. Come closer to the present and that agreement evaporates into thin air. As Mitchell insightfully observes in his aptly titled book Ambivalent Europeans, the Maltese have an 'awkward relationship with their history and identity' (Mitchell 2002: 31).

\section{Which icons for the coins? ${ }^{12}$}

The choice of the designs to grace Malta's euro coins illustrates this dilemma (see Figure 3). First, four themes had been chosen, 'each one capturing a specific aspect of the Maltese national fabric', with three different options presented for each theme. Yet, none of these twelve options included an actual Maltese person, or a contemporary Maltese trait - except the official coat of arms of the state (which, by the way, has been changed twice since independence), and which was ultimately one of three images selected. (The monument commemorating the Great Siege of 1565 was included under the Modern Malta theme!) The allegoric figure of Malta was one of the options on offer. Eight of the options represent images of structures from Malta's history 


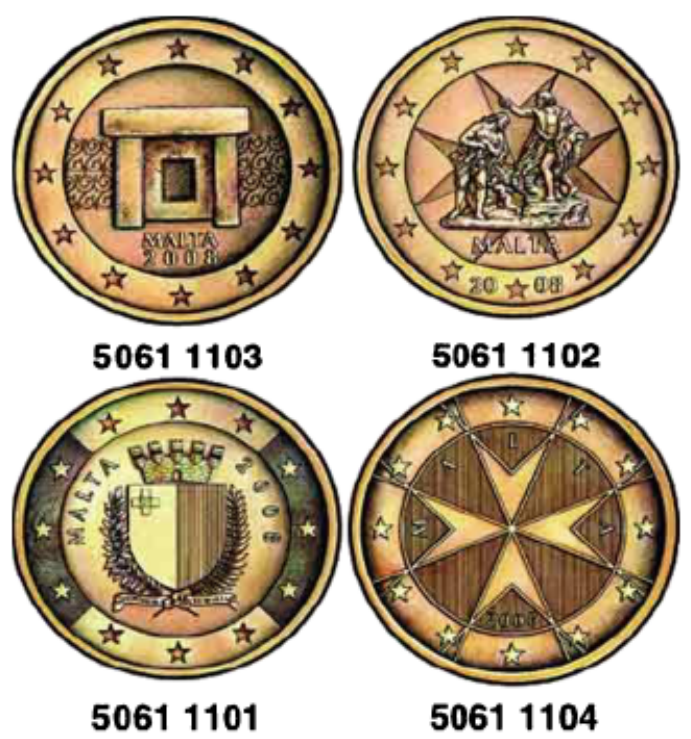

Figure 3. The coin faces which made it, and the one which did not: Mnajdra Prehistoric Temple, the Coat of Arms of the Republic of Malta and the 'Maltese Cross' represent the selected three coin faces for the Maltese euro coins. The 'Baptism of Christ' (top right) was eventually sidelined. (C) Central Bank of Malta.

or prehistory, ranging from megalithic temples to the Valletta fortifications. Eventually, the most popular choice of image turned out to be the Italian sculptor Giuseppe Mazzuoli's Baptism of Christ in St John's Co-Cathedral, in Malta's capital city. This choice was the subject of a frenzied local campaign to have a religious theme imposed on the coins and thus perhaps exact sweet and symbolic revenge for the EU's refusal to acknowledge its Christian traditions in its draft Constitution. But, as things turned out, it was the Maltese authorities themselves that withdrew this controversial image from the running, precisely because of its distinct religious connotations (Grima 2006a). Meanwhile, the so-called 'Maltese Cross': now a national symbol of Malta, but actually the symbol of the Sovereign Military Order of Malta which was not one of the initial options flagged for consideration - was also selected as an image for the coins. Ironically, the absence of the 'Maltese Cross' from the initial set of options was explained as due to it being '.... nonMaltese or normally associated with the Order of St John', which is a religious organisation (Grima 2006b). (This objection has apparently been subsequently, and quietly, overruled.) The third image to make it was that of the façade of the Mnajdra megalithic temples, a World Heritage Site. Catholicism remains the closest reference point to Maltese nationalism, while the country blandly appropriates alien symbols (including crosses, sculptures and the artefacts of long-eclipsed civilisations) as its own. 
But, what else has happened since, or because of, Malta's accession to the EU in May 2004? Has the EU served as the appropriate 'other' around which Maltese nationalism can find some expression and manifestation?

In my 2002 paper, I had written that one of Malta's four fears from EU accession, if not the strongest fear of all, was the fear of invasion. From entrepreneurs, from students, from workers, from expatriates buying up property ... there is a cultural understanding of Malta as being small, islanded and therefore fragile; of the Maltese culture and language being unique; and that, if the Maltese were to allow themselves to be taken over, numerically, by 'immigrants' - which wouldn't take much - then their future would be at risk (see also Spiteri 2004a). This argument has been presented (and largely accepted) in the course of EU Accession negotiations, leading to Malta securing the only permanent derogation given to the ten acceding countries in 2004: preventing non-residents from the purchase of second homes on the island (The Economist 2004).

\section{'Invaders', by the boatload}

But, as is typical of most invasions, the threat has materialised from an unexpected source.

As if the current demographic strain is not enough, ${ }^{13}$ Malta finds itself deliberately or, more likely, just serendipitously - as the unwitting victim of a 'new vulnerability' (Sammut 2007): the landfall of undocumented migrants escaping oppression, war, poverty and discrimination and/or heading for the bright lights of Europe. During 2005, a total of 1,800 immigrants reached Malta illegally, practically all drifting in by boat. In 2006, another 1,780 illegal immigrants arrived (see Figure 4). The situation was very soon claimed by the authorities and the media to have reached crisis proportions: browsing for news about Malta on the international media or via internet search engines, the in-migration issue comes up repeatedly. ${ }^{14}$

The situation is delicate because it has the potential to destabilise the political atmosphere which has dominated Malta over the last few decades. Although originating in clearly identifiable and distinct social classes, the two main political parties in Malta have become increasingly shorn of ideological principles or divides with time. As catch-all parties operating in an open economy, they have limited room for manoeuvre: they are obliged to woo the centre ground of politics and promote liberal economic strategies that are attractive to foreign investment, while respecting Malta's ambivalent corporate culture: strongly unionised in the public sector; but strongly familial and non-unionised in the construction industry and in all small and medium-sized firms. The political parties have had even less room for manoeuvre since January 2008, when the euro was adopted as the national currency; and they know it.

(C) The author 2009. Journal compilation (C) ASEN/Blackwell Publishing Ltd 2009 


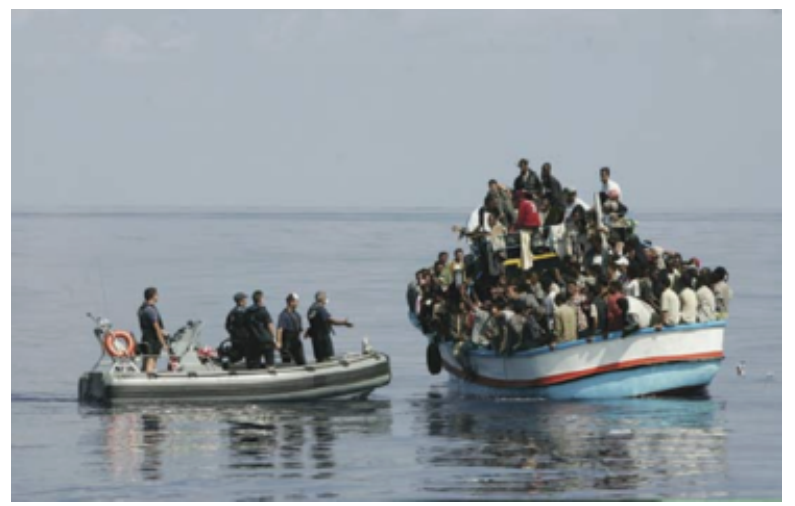

Figure 4. Mediterranean encounters: Malta Armed Forces personnel investigate a vessel packed with would-be undocumented immigrants. Photo by Darrin Zammit Lupi for The Times, Malta, 25 September 2005. (C) Allied Newspapers Limited/ Reuters/Corbis.

Undocumented migrants may threaten this balance. Part of their impact is predictable, and speaks to Malta's relative attraction as a 'developed' economy. Irrespective of whether the transit to Malta was planned or haphazard, immigrants who land in Malta would quickly find out that the going rates of pay in the Maltese labour market are much more generous than anywhere in North Africa or the Middle East. (The industrial minimum wage in Tunisia, Malta's closest African [and non-EU] neighbour, is less than US\$200 a month; in Malta, it is about US\$200 a week.) Even where wages are not always determined rigorously and scrupulously in terms of legal principles - as is common practice in the quarrying and construction industries (for men) as well as the cleaning and food preparation industries (for women) take-home pay is typically very acceptable to newcomers arriving from North Africa or the Middle East. In turn, these individuals can prove to be attractive to employers who wish to maintain lax 'hire and fire' practices (easily maintained with the real threat of being reported to the police and eventually evicted) while paying lower wages and securing high levels of productivity in jobs that, frankly, many Maltese of working age, able to register for unemployment benefit, no longer find attractive: stone quarrying, construction, plastering and ship-repair (for men); cleaning and housekeeping (for women). Regrettably, such clandestine employees often only become visible to the public eye when they become victims of occupational accidents.

Another likely tangible effect of undocumented migration is to be seen on the political front. In other countries, notably the Netherlands, Denmark and Australia, anti-immigrant parties or policies have made strong inroads into traditional politics, destabilising the consensuality that characterised much of the post-war period. In Malta, the MLP and the NP are so strongly entrenched at a local level (all the more so since local councils were 
introduced) that they may be justified in believing that no such wave of immigrant-driven politics - whether in favour or against - is likely to affect them and their robust power bases. And yet, their snug non-response has already been somewhat jolted by an emerging anti-immigrant factionalism. An explicitly exclusivist, anti-immigrant party, the National Action (Azzjoni Nazzjonali - AN), contested general elections for the first time in Malta in 2008. It joins another right-wing outfit, Imperium Europa (Empire Europe) whose stated goal is to unite all European natives under one flag - set up in 2000 by Norman Lowell, and who contested the first European Parliament elections held in Malta in June 2004, obtaining 1,603 first-count votes from a total of 250,691 votes cast ( 0.64 per cent): the best ever showing by an independent candidate in a nation-wide election since 1966. This neo-Aryan, anti-immigrant message did not make much headway in the latest general election; ${ }^{15}$ but it commands a certain local appeal, and breaks away from the (superficial?) veneer of Catholic neighbourly charity. While it is avowedly anti-nationalist - indeed, Lowell has denigrated the Maltese language and all Malta's cultural links with North Africa, striving for a European and Latin ideal that acts as a bulwark against encroaching Islam - it can nevertheless also stimulate a wave of nationalism that otherwise remains absent in Malta. Moreover, a dramatic immigrant-related episode at a local level may lead to some interesting repercussions in a particular electoral district. ${ }^{16}$ This is probably something that is waiting to happen.

The political parties themselves would probably be undergoing their own internal debates as to how to respond to the 'immigrant threat'. They are caught between the doves (the champions of human rights, Christian hospitality and individual freedoms) and the hawks (advocating clampdown, 'strong-arm' tactics and policies - such as detention - otherwise meant to make Malta less attractive to both current and potential undocumented immigrants). These factions exist within both parties, with the hawks (so far) in the ascendant within both (Spiteri 2004b).

Meanwhile, the EU presents a welcome 'front' to this issue, transforming the matter into one of regional (and not just national) concern. Malta has indeed been flexing and testing its newly found status and diplomatic muscle as a member of the EU with the immigration file top-most, ensuring that the EU takes some collective responsibility for the matter. Partisanship has not always driven this agenda: Malta has five elected representatives in the European Parliament (three MLP; two NP), and all five adopted a common position calling for amendments to the Dublin II agreement and for the European Commission to give more assistance to Malta in handling the immigration 'menace'. ${ }^{17}$ These are Malta's first-ever experiences of federalist politics, and clandestine immigration is the main issue that is driving the Maltese effort at this time.

The issue already presents an interesting dilemma: on the one hand, Malta is no longer just an independent sovereign state but is the EU's southernmost bulwark. The country has taken on a concern with the security of Europe's 
borders as part of its new status. Thus, the undocumented migrants reaching Malta's shores are also reaching Europe's shores: they are therefore presumably a European problem requiring a European solution. Meanwhile, however, this hoped-for solution is not in sight. A couple of EU member states have agreed to take a dozen of these migrants as refugees; but this is hardly going to provide a lasting reprieve from a situation that is not likely to go away in the near future. Growing frustration on the part of the Maltese at what can be easily perceived as a crass dismissal by a distant and insensitive Brussels of a puny Malta can fuel an 'anti-EU' nationalism that can feed on the various fears and suspicions of European incorporation which led to the strongest negative vote in pre-accession referenda amongst the ten accession countries in $2003 .{ }^{18}$

\section{Constructing nationalism}

The task of constructing nations and nationalism has been difficult in many Pacific island states ...: they came to independence without any struggle against colonialism ...(Connell 2007: 85).

John Connell's caustic observation holds true also for Malta, and is actually a characteristic of former island colonies that were incorporated into colonialism not for economic exploitation but for strategic purposes, obliging the engineering of sympathetic colonial subjects by colonial administrations. A weak national (that is, Cypriot) identity may also help to explain the intractable 'Cyprus problem', with Hellenic or Turkish identities continuing to exercise a significant influence over explicitly island ones (e.g. Baldacchino 2002b; Mavratsas 2007).

Moreover, since Malta became a republic in 1974, none of its Heads of State - who should typically serve as individuals that stand aloof from party politics and facilitate national unity - have ever been directly elected but have rather been nominated from the ranks of senior governing party politicians, and never with the support of both sides of the House, thus seriously damaging their chances of acting as national icons. ${ }^{19}$ Only one of these Heads of State, Agatha Barbara, the only woman to have served as President of the Republic of Malta, had her portrait appear on a Malta bank note. This choice was so controversial that her facial image only appeared on one bank note series; ${ }^{20}$ and no other Maltese Head of State has had this honour.

Indeed, returning to the notion of currency portrayals as indicative of symbols of national unity, the Central Bank of Malta has printed the face of a Maltese on a bank note on only one other occasion: ${ }^{21}$ instead, it has since opted to reproduce a stylised allegoric image of Malta, a schematic female figure that does not have any roots in local history or representation, ${ }^{22}$ having appeared mainly as a regular caricature in one local newspaper, and then adopted in 1989 as the personification of the nation on a monument commemorating twenty-five years of independence (see Figures 5, 6 and 7). Placing the image of an actual person on a bank note would most likely 

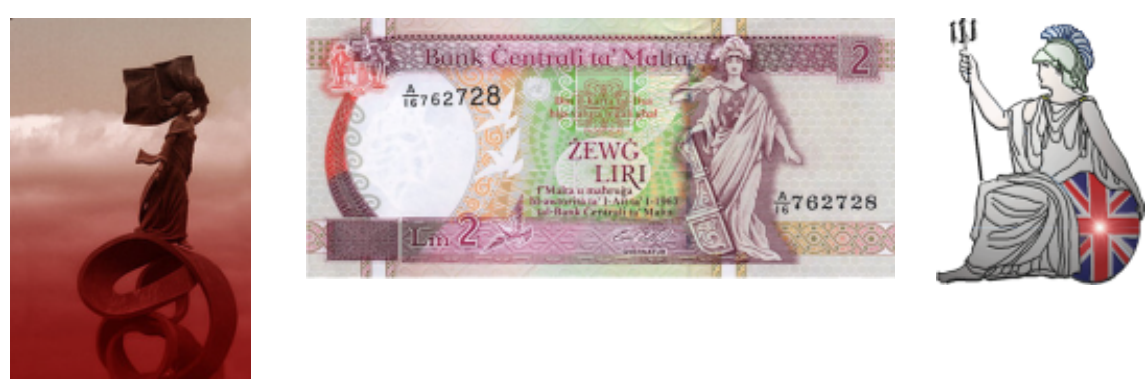

Figures 5, 6 and 7. Allegorical females: The Malta Independence Monument, Two Malta Liri Bank Note and Britannia. (C) Department of Information, Malta; Central Bank of Malta; Pip Wilson - http://www.wilsonsalmanac.com/book/mar24.html respectively.

alienate half the population, reaffirming how the 'weak state' (following Hyden 1983) and its symbols are, or are seen to be, captured by a specific political party. And so, in its blandness, allegoric Malta has avoided controversy. In this and other ways, the state apparatus continues to proffer constructions of nationhood which are really nothing but symbols of a nationless polity, coupled with an unwavering, hegemonic, partisan fatigue.

It should not therefore be surprising to find limited and safe eruptions of national pride by a citizenry so far starved of such symbolism, or otherwise obliged to consume religion as the expression of kitsch, almost banal, cultural nationalism. ${ }^{23}$ Recent empirical research by Abela (2006: 23-4) suggests that 'Maltese national pride, or the emotional dimension of an inherited Maltese identity, is significantly related primarily to people's attachment to the [Catholic] Church and religion', or else, is withdrawn to seek affiliation with a private institution: the family, to the extent that the strong role played by religion may actually undermine nationalism.

While it lacks corroborative evidence, ${ }^{24}$ this paper supports the views of Billig (1995), Cram (2006: 1) and Schmitter (2005) who warn that a proper understanding of the process of European integration at the grass-roots level may be driven more by low-profile, 'day-to-day' or 'banal' events than grand, constitutional politics. While one should not discount the influence of EU membership on the Maltese psyche in the medium to long term, the 'significant other' so far has not been a diffident Brussels bureaucracy but the Sudanese migrant who entered Maltese waters seeking safe refuge in Europe. Mind you, the two referents may yet combine as the complementary facets of a tragic narrative, if the EU is felt by an increasingly racistxenophobic Maltese ${ }^{25}$ to be avoiding, or even obstructing, an adequate response to the 'immigrant threat'. Being part of the EU has encouraged the evolution of a secular, national character in Malta from a somewhat unlikely quarter.

When the current President of the Republic of Malta, Edward Fenech Adami, was appointed (in spite of the MLP's objections) in 2004, after serving 
since 1977 as the leader of the Nationalist Party, he argued that Malta's 'system of confrontational politics is positive in the sense that it provides stability'. In this way, the bimodality of Maltese society - its starkly 'in or out' politics (Richards 1982) - is seen as conducive to a political steadiness, with some of its legitimacy obtained from the altercations of power between two 'catch-all' parties. Such a 'stability' makes short shrift of serious attempts at constructing nationalism; although, as this paper has sought to demonstrate, popular desires for a unifying symbolism - a popular (as against an elitedriven) nationalism - continue to break surface and render themselves manifest.

If nationhood is a fiction, a necessary imaginary (following Anderson 1983) in the rhetoric of modern politics, then today's Maltese appear fully absolved from this mirage. Most will continue, in their day-to-day lives, to seek a spoils-based leadership from their preferred politician (for material goods) or priest (for spiritual ones). But the rupturing of this utilitarian routine by expressions of national pride or manifestations of what are perceived as threats to the Maltese partisan polarity may suggest that some sense and expression of commonality is achievable, even if only at a temporary and visceral level.

Finally, the presses of the two political parties regularly churn out populist interpretations of history, which are then sold to the party faithful during mass party activities. But, in such a polarised society, the local professional historians and sociologists who read and interpret 'the signs of the times' are themselves liable to being associated with a particular party ticket, even if they themselves may object to that interpretation. Mitchell (2003) very cleverly (for a non-Maltese) charts the emergence of a project to historically establish a Maltese national identity by Maltese academics in the late 1980s. With my own attempts to critique this project - a criticism which ironically also contributes to the same project - I am easily associated with a particular political camp, even though that presumed affiliation does not necessarily reflect my past voting patterns or current preferences.

\section{Notes}

1 For example, in Slovenia (the first 2004 EU accession country to make the euro changeover), 132 tenderers from the general public proposed 699 motifs.

2 The term, coined by Anthony D. Smith, describes a pre-national, ethno-cultural group with these prerequisites: a collective name, a myth of descent, a shared history, a 'distinctive shared culture', an association with a particular territory, and a sense of solidarity. See Smith (1988). Both Laburisti and Nazzjonalisti (Labourites and Nationalists in Malta) qualify.

3 Mørkøre (1996) develops this argument to explain the relationship between the Faroe Islands and Denmark.

4 The Maltese Language Act, Chapter 470 of the Laws of Malta, Act 5 of 2004.

5 A powerful residue of these irredentist campaigns is the persisting passionate loyalty and rivalry of the Maltese for the Italian and English football teams, respectively. 
6 A situation that may be paralleled by the Greek Orthodox Church in Cyprus, especially when that island was still a British colony.

7 Jamaica is a more extreme example of a partisan-split island society, where 'gang wars' between supporters of the People's National Party and the Jamaica Labour Party have been common in the run-up to elections.

8 Apart from Independence Day and Freedom Day, these also include: 7 June (commemorating a Maltese uprising in 1919); 8 September (commemorating the lifting of the Great Siege in 1565, as well as the Feast of Our Lady of Victories); and 13 December (commemorating the declaration of Malta as a Republic in 1974).

9 Hundreds of ecstatic fans welcomed singer Ira Losco at the Malta international airport when she returned from the Eurovision Contest (which is taken very seriously in Malta). Suggestively, she had a Maltese Flag around her neck.

10 Ignatieff (2000) defines patriotism as 'strong nationalistic feeling for a country whose borders and whose legitimacy and whose ethnic composition is taken for granted'.

11 Does the Maltese Nation Exist? Bondiplus, 21 January 2003 (Television Malta). http://www. di-ve.com/dive/portal/portal.jhtml?id $=77133 \&$ pid $=149$.

12 The word icons happens to be an anagram for coins.

13 With 400,000 residents perched on $316 \mathrm{~km}^{2}$, Malta has one of the world's highest population densities for a sovereign state. Some 1.2 million tourist visits annually add to the strain.

14 A list of pertinent media releases can be found at: http://www.maltamedia.com/features/io/ 2005/08/index.shtml.

15 In the general elections held on 8 March 2008, Imperium Europa, represented only by Norman Lowell, obtained eighty-four 'first count' votes; National Action obtained 1,461. These amount to 0.53 per cent of the total votes cast.

16 The Maltese Islands are divided into thirteen electoral districts, from each of which five candidates are elected, on the basis of a 'single transferable vote', proportional representation system.

17 Dublin II obliges receiver countries to deal with asylum seekers. It is deemed to penalise Malta as a small, front-line state. Through the European Parliament, the MEPs tabled a motion (5 April 2006) demanding, among other things, a mechanism allowing a quota of those landing in Malta to be taken in by other EU nations. http://www.europarl.europa.eu/sides/getDoc.do?type = MOTION\&reference $=$ P6-RC-2006-0241\&language $=\mathrm{EN}$.

18 With a ninety per cent turnout - low, by local standards -53.5 per cent of voters approved Malta's accession to the EU in a March 2003 referendum.

19 Only an acting President of the Republic, Paul Xuereb (1987-1989), received cross-party support for his nomination.

20 This was the fourth series issued by the Central Bank of Malta in 1986. Currency is showcased at: http://www.centralbankofmalta.com/site/currency2d.html.

21 This was the portrayal of Prime Minister and Nationalist Party Leader Gorg Borg Olivier, who secured independence for Malta in 1964.

22 Unlike, say, Britannia, to which however 'Malta' does have an uncanny resemblance (see Figure 7).

23 For example, it is almost impossible to speak secular Maltese without regular references to God (Alla).

24 I agree with my colleague Peter Mayo (personal communication, 25 March 2008) that 'the subject needs to be explored at a deeper level with some interviews to provide some sense of how people make sense of their world, their sense of the context in which they live, and what type of 'imagined community', if any, they dream up'.

25 A poll in August 2005 found that more than ninety per cent of respondents had no objection to having a European neighbour, but an equal number said that having an Arab or African neighbour was 'highly undesirable'. Moreover, more than seventy-five per cent of respondents claimed that they would not give shelter to persons who were trying to escape their native land because of political persecution, war, civil war, hunger or mass poverty. See Vassallo (2005). 


\section{References}

Abela, Anthony M. 2006. 'Shaping a national identity: Malta in the European union', International Journal of Sociology 35, 4: 10-27.

Anderson, Benedict 1983. Imagined Communities: reflections on the Origins and Spread of Nationalism. London: Verso.

Baldacchino, Godfrey 1988. 'The industrialization of Malta: a historical analysis of the formation, control and response of labour', in E. Azzopardi and P. Heywood (eds.), Issues. Malta: New Economics Society.

Baldacchino, Godfrey 2002a. 'A Nationless State? Malta, National Identity and the European Union', West European Politics 25, 4: 191-206.

Baldacchino, Godfrey 2002b. 'Jurisdictional self-reliance for small island territories: considering the partition of Cyprus', The Round Table: Commonwealth Journal of International Affairs 91365: 349-360.

Baldacchino, Godfrey 2004. 'Autonomous but not Sovereign? A review of Island sub- nationalism', Canadian Review of Studies in Nationalism 31, 1-2: 77-89.

Billig, Michael 1995. Banal Nationalism. London: Sage.

Busuttil, Salvinu 1965. 'Malta's economy in the nineteenth century', Journal of the Faculty of Arts 3: $1-22$.

Chircop, Saviour 1994. 'As we sit together, should we use the phone? A research agenda for the study of the media in Malta', in R. G. Sultana and G. Baldacchino (eds.), Maltese Society: a Sociological Inquiry. Malta: Mireva.

Connell, John 2007. 'The Fiji Times and the good citizen: constructing modernity and nationhood in Fiji', The Contemporary Pacific 19, 1: 85-109.

Cram, Laura 2006. 'Identity and Integration Theory: Diversity as a Source of Integration', paper presented at SNES Conference, Umeå, Sweden, March 17-18.

Edmond, Rod and Vanessa Smith (eds.) 2003. Islands in History and Representation. London: Routledge.

Franklin, Mark N. 2004. Voter Turnout and the Dynamics of Electoral Competition in Established Democracies since 1945. Cambridge: Cambridge University Press.

Frendo, Henry 1979. Party Politics in a Fortress Colony: the Maltese Experience. Malta: Midsea Books.

Grima, Noel 2006a. 'Competition to choose Malta Euro coin set', The Malta Independent, 21 March, http://217.145.4.56/ind/news.asp?newsitemid $=26727$.

Grima, Noel 2006b. 'EU may find problems with Malta's choice for the Euro coins', The Malta Independent, 21 March, http://217.145.4.56/ind/news.asp?newsitemid $=27792$.

Grixti, Joseph 2006. 'Symbiotic transformations: youth, global media and indigenous culture in Malta', Media, Culture and Society 28, 1: 105-122.

Hannerz, Ulf 1996. Transnational Connections: culture, People, Places. London: Routledge.

Hirczy, Wolfgang 1995. 'Explaining near-universal turnout: the case of malta', European Journal of Political Research 27, 2: 255-272.

Hoefte, Rosemarijn and Oostindie, Gert. 1989. 'Upside-down decolonization', Hemisphere 12: $28-31$.

Hull, Geoffrey 1993. The Malta Language Question: a Case History in Cultural Imperialism. Malta: Said International.

Hyden, Goran 1983. No Short Cuts to Progress: African Development Management in Perspective. Berkeley, CA: University of California Press.

Ignatieff, Michael 2000. 'Battle without Blood', an interview with Max Garrone for www. Salon.com, May 4.

http://archive.salon.com/books/int/2000/05/04/ignatieff/index.html

Jacobs, Dirk and Maier, Robert. 1997. 'European identity: construct, fact and fiction', in M. Gastelaars and A. de Riuter (eds.), A United Europe: the Quest for a Multifaceted Identity. Maastricht: Shaker. 
Lijphart, Arendt 1968. The Politics of Accommodation: Pluralism and Democracy in the Netherlands. Berkeley, CA: University of California Press.

Mavratsas, Caesar V. 2007. 'European Accession and Cypriot Identity: Ethnic Nationalism, the Underdevelopment of Civil Society, and the Future of Europeanisation', paper presented at Ross Priory Workshop, Loch Lomond, Scotland, 24 April.

McElroy, Jerome L. and Mahoney, Mary. 1999. 'The propensity for political dependence in Island microstates', INSULA: International Journal of Island Affairs 9, 1: 32-35.

Micallef, Joseph V. 1979. 'Mediterranean Maverick: Malta's uncertain future', The Round Table: Commonwealth Journal of International Affairs 69275: 238-251.

Mitchell, Jon P. 2002. Ambivalent Europeans: ritual, Memory and Public Sphere in Malta. London: Routledge.

Mitchell, Jon P. 2003. 'Looking forward to the past: national identity and history in Malta', Identities: Global Studies in Culture and Power 10, 2: 377-398.

Mørkøre, Jogvan 1996. 'The Faroese home rule model: theory and reality', in L. Lyck (ed.), Constitutional and Economic Space of the Small Nordic Jurisdictions. Stockholm: NordREFO.

Payne, Anthony 1991. 'Britain and the Caribbean', in P. K. Sutton (ed.), Europe and the Caribbean. London: Macmillan.

Richards, John 1982. 'Politics in small, independent communities: conflict or consensus?', Journal of Commonwealth and Comparative Politics 20, 2: 155-171.

Risse, Thomas 2003. 'The Euro between National and European identity', Journal of European Public Policy 10, 4: 487-505.

Sammut, Carmen 2007. 'The Ambiguous Borderline between Human Rights and National Security: Journalists' Dilemmas in their Reportage of Irregular Immigrants in Malta', Global Media Journal, Mediterranean Edition, forthcoming.

Schmitter, Philip 2005. 'Ernst B. Haas and the legacy of neofunctionalism', Journal of European Public Policy 10, 4: 487-505.

Serracino-Inglott, Peter 1988. 'Was Malta a nation in 1964?', in V. Mallia-Milanes (ed.), The British Colonial Experience 1800-1964: the Impact on Maltese Society. Malta: Mireva.

Sidaway, James D. 2001. 'Rebuilding bridges: a critical geopolitics of Iberian trans-frontier cooperation in a European context', Environment and Planning D: Society and Space 19, 6: 743-778.

Smith, Anthony D. 1991. Nationalism and Modernism. London: Routledge.

Smith, Anthony D. 1998. The Ethnic Origins of Nations. New York: Wiley Blackwell.

Smith, Anthony D. 2004. 'History and national identity: responses and clarifications', Nations and Nationalism 10, 1-2: 195-209.

Spiteri, Sharon 2004a. 'Through the Looking Glass, Darkly', 22nd September, http://www. lostinthought.ws/portfolio/lookingglass.html.

Spiteri, Sharon 2004b. 'Detention is not a Deterrent', 23rd September, http://www. lostinthought.ws/portfolio/lookingglass.html.

Srebrnik, Henry F. 2000. 'Identity, culture and confidence in the global economy', in G. Baldacchino and D. Milne (eds.), The Political Economy of Islands in the North Atlantic: the Resourcefulness of Jurisdiction. Basingstoke: Macmillan.

The Economist 2004. 'Smallness Pays', London, The Economist Intelligence Unit, 26 February, http://www.economist.com/displayStory.cfm?story_id $=2461814$.

van Houtum, Henk and Strüver, Anke. 2002. 'Where is the border?', Journal of Creative Geography 4, 1: 20-23.

Vassallo, Mario 2005. A Report on a Study of Racism Prepared for Allied Newspapers Limited, unpublished report. Malta: Progress Press.

Vella, Mario 1994. 'That favourite dream of the colonies: industrialization, dependence and the limits of development discourse in Malta', in R. G. Sultana and G. Baldacchino (eds.), Maltese Society: a Sociological Inquiry. Malta: Mireva.

Zammit, Edward L. 1984. A Colonial Inheritance: Maltese Perceptions of Work, Power and Class Structure with reference to the Labour Movement. Malta: Malta University Press. 